\title{
The HISTORY OF THE CAVE-ChURCh IN COPTIC EgYPT
}

\author{
Heba Magdy \\ Lecturer, Guidance Department \\ Faculty of Tourism and Hotels, Alexandria University
}

\begin{abstract}
The paper spots the light on the origin of the Cave-Shrine in ancient Egypt: how it appeared in the Pharaonic period, disappeared, and reappeared in the Byzantine period in the so-called the Cave-Church. The researcher classified the Cave-churches founded in Egypt into four categories.
\end{abstract}

\section{Introduction}

As long as Egypt contains many areas that full of mountains, normally we found caves inside. The ancient Egyptians progressively enhanced these natural existed caves until they were buildings altogether,or until they appeared as buildings carved into thesolid rock. The Egyptians used these caves in their worship. The god in the ordinary citytemples repeated theFirst Time when god emerged from the waters of chaos on the primeval mound. However, in the cave-shrine resembles the womb from which the god will be born. The cave-shrine is considered a link between our world and the mysterious dark side.The difficulty of this research is attributed to the fact that it was not easy to trace the cave-shrines, as they can be easily mistaken for the rock-cut shrines (those that had been carved by man in the mountain from the start to finish). I will depend on the early description of the shrines, and if there were other natural caves existed in the mountain.

The earliest example of these cave-shrines can be found at Elephantine where the earliest shrine of goddess Satet was carved during the first or the second dynasty in the granite rocks of the cataract just below the existing reconstructed temple (Pl. 1). ${ }^{1}$ The early dynasties revealed also many cave-shrines in ancient Nubia. ${ }^{2}$

The $12^{\text {th }}$ dynasty provided us with the temple of Hathor at Serabit El-Khadem (Sinai). This temple began as two caves dedicated to Hathor (Pl. 2). The cave-shrine was some kind of porch approached by an avenue of freestanding stelae. Over time new rooms were added. In the $18^{\text {th }}$ Dynasty new expansions were undertaken: a long series of halls were built in one line, giving the temple its modern day appearance that is known as Serabit El-Khadim. ${ }^{3}$ There were caves in the vicinity in which the worshippers slept so that their dreams (inspired by the goddess) could tell them where to search for the precious turquoise. $^{4}$

Similar cave-shrines from the Middle Kingdom were found at MersaWadiGawasis, a middle kingdom port on the Red Sea). Six of these shrines were found overlooking the Red Sea. Three of them consisted of circular mounds of coral rocks covered by gravel, with two small internal chambers. One shrine consisted of an oval enclosure of rocks (fossil coral and conglomerate), inside of which is a small U-shaped stone. The 
last shrine is a large open U-shaped space within a gravel mound. Stelae were found related to these shrines suggesting that they were dedicated to a marine deity. Another cave-shrine was found to the east of the cave of ropes. Offerings were left there including Minoan pots and rods of ebony, as well as an offering stela mentioned a maritime deity accompanied by Osiris of Wadj-wer and Horus. ${ }^{5}$ Another cave-shrine was found near the mining site at Gebel Zeit, Red Sea. This shrine was transformed into a sanctuary in the New Kingdom dedicated to Hathor, Horus, and Min of Coptos. ${ }^{6}$

The researcher thought that the temple of SpeosArtemidos (Pl. 3) that is located in WadiBatnBaqara at Beni Hassan was originally a cave-shrine for the goddess Pakhet from the Middle kingdom. Although, no traces of this earlier shrine were found, there are some evidences that proved this opinion. Pakhet was an ancient Egyptian goddess whose cult-centre was at Beni Hassan, as it was mentioned in the inscriptions found inside the Middle kingdom tombs at Beni Hassan. ${ }^{7}$ Moreover, It is known that this type of cave-shrines flourished in this period, especially that there is a record of mining expeditions sent to Beni Hassan during the Middle Kingdom. It is well known that it was a habit of carving cave-shrines in the mining spots. It seems that this caveshrine was developed later by Hatshepsut to be a rock-cut temple.

However, the real spread of the cave-shrine dates back to the New Kingdom; as numbers of these shrines were found. This can be noticed in the Theban Mountain, precisely near the village of Deir El-Medineh. These cave-shrines were dedicated to Ptah, Meretseger, Osiris, Isis and Hathor (Pl. 4). ${ }^{8}$ There is also the Hathor shrine at Deir el-Bahari, that Naville thought that it may be originally a cave, where Hathor was supposed to have suckled Hatshepsut. Afterwards, Hatshepsut enlarged the cave, added colonnades, adorned it with sculptures, and made the beautiful shrine part of her temple. ${ }^{9}$ When Tuthmosis III closed the temple of Hatshepsut, he established a new temple at Deir El-Bahari and also a new cave-shrine of Hathor (Pl. 5). This shrine was carved in his temple that is located between the temple of Hatshepsut and that of Mentouhotep. It is about 10 feet long. It has been lined all round with slabs of sandstone while the roof took the shape of a vault. Apparently, the shrine was in use up to the Ramesside period, when it was destroyed by an earthquake. ${ }^{10}$ The shrine together with the sculpture of the cow has been transferred to the Egyptian Museum in Cairo.

Later on, kings of the New kingdom no longer used the natural caves in their worship. Instead they carved their shrines inside the rock, an art that is known as the rock-cut art. Examples of these rock cut shrines could be seen at Gebel El-Silsila, is located between KomOmbo and Edfu. It contains many cave-shrine (around 32 ones on the western bank) dedicated to a variety of Nile gods and to the river itself. ${ }^{11} \mathrm{~A}$ new innovation appeared in the New Kingdom, which is the rock-cut temple. Although the Greeks called this temple a Speos (Literally means: cave); it doesn't mean that this is a natural cave. The word Speos in archaeology refers to the rock-cut temple. There is the Speos of Horemheb that was cut in Gebel el-Silsila. ${ }^{12}$ The same king built another speos temple at Abahuda in Nubia (Gebel Adda) just south of Abu Simbel dedicated to Amun-Re, Thoth and local deities. ${ }^{13}$ King SetiI carved a rock-cut temple at Kanais 
dedicated to god Amun-Re. Kanais is a Wadi located in the eastern desert opposite the town of Edfu. ${ }^{14}$ However, Ramses II is considered the king who carved more than one rock-cut temple. He carved six temples in Lower Nubia some of them were wholly carved in the rock such as the temple of Beit el-Wali dedicated to Amun-Re, the two temples of Abu Simbel dedicated to Amun-Re, and the temple of El-Derr dedicated to Re-Horakhty. Others were partially carved in the rock such as WadiEs-sebua temple dedicated to Amun-Re (only the inner vestibules and the sanctuary were cut in the mountain), temple of Gerf Hussein dedicated to Ptah (only the pillared hall, the hall of offering and the sanctuary are carved in rock). ${ }^{15}$

In the Graeco-Roman period, we didn't find a record about a cave-shrine except the large cave that was found in the cliffs of Tehna, El-Minya; over which there is an inscription in Greek letters. The inscription dates back to the reign of Ptolemy V and mentioned that the cave is consecrated to goddess Isis Mokhias. ${ }^{16}$ The village of Tehna El-Gebel was called during the Graeco-Roman period "Akoris". The village was once a site for limestone mining, as series of large limestone quarries have been discovered to the north and the south of the village. At Taifa, Nubia, a cave-shrine was found and dates back to the $4^{\text {th }}$ century AD. It could be the latest constructed cave-shrine. ${ }^{17}$

The habit of carving temples out of the rock continued in the Graeco-Roman era. This appeared in the Ptolemaic hemispeos temple at el-Kab (about $15 \mathrm{~km}$ north of Edfu) dedicated to the lion goddess Seshmetet. It was built by Ptolemy VIII and IX. ${ }^{18}$. During the late Ptolemaic period, a rock-cut temple is dedicated to Asklepios at Athribis (now the village of Wannina, $6 \mathrm{~km}$ west of Sohag) ${ }^{19}$ Akoris, now the village of Tehne el-Gebel at El-Minya, was a site of large limestone quarries. The Roman period gives us some rock-cut chapels and temples. The most important is the temple of Amun that was known as Temple B, or the temple of Nero. There is also Temple C, lies on the mountain at the beginning of WadiTihnawi. ${ }^{20}$ This temple is dedicated to Zeus-Helios-Serapis. $^{21}$

It seems that the concept of carving a cave-shrine was very limited in the early periods of the Pharaonicera to the area of Nubia. Thus we can assume that this habit was a Nubian invention. In the Middle Kingdom, the artist began to carve the caveshrines at Sinai and the red sea. The cave-shrines that were carved during this period related to the mining expeditions that were sent to Sinai and the Red Sea. The carving of cave-shrines exceeded in the beginning of the New Kingdom and was replaced later by rock-cut shrines and temples. It is notable also that the divinity to whom most of the cave-shrineswere dedicated was either Amun or Hathor). God Amun was originally the god of invisibility; therefore it is not surprising to find a relation with the caves. During the Middle kingdom goddess Hathor was the one who was invoked inside the caves. The ancient Egyptian myth used to relate Hathor with the cave. In the book of the dead there is a plate showing Hathor emerging from the slope of a mountain (logically from a cave) (Pl. 6). ${ }^{22}$ The Graeco-Roman period, provided us with only one example of the cave-shrine which is the one found at Tehne. On the contrary this era provided us with numerous examples of rock-cut shrines. 
Thecave-shrines reappeared in the Byzantine era in what is called the cavechurches. It is worth mentioning here that some scholars confused between the cave and the crypt. The crypt will not be discussed in this research, as it was defined as a stone chamber beneath the floor of a church. Originally, crypts were typically found below the main apse of the church, but were later located beneath the naves. These crypts were mainly used for burial purposes (the burial of the Martyrs), an example can be found in the crypt under the church of Abu Mina. Sometimes the crypts were dug for the residence of the hermits. ${ }^{23}$

The researcher divided the cave-churches into four categories: The hermits caves ${ }^{24}$, the refuge caves that were used during the persecution of the Romans. The caves could be also that in which the holy family hid during her holy journey to Egypt(Many caves of this concept scattered in the whole land of Egypt). Cave-churches established in a Christian community inhabited the area of the mountains.

\section{Refugee caves}

We will start with the cave-churches that were once inhabited by the saints who escaped from the persecution and sought refuge in these caves. Two examples can be traced in Egypt. The first one is that cave-church of Saint Paul by the red sea. The first hermit that occupied the caves of the Red Sea Mountain was Saint Anthony. Then a monastic settlement was established in this area during the reign of Julian the Apostate $\left(361\right.$ - 363 AD) ${ }^{25}$ We will discuss neither that of Anthony nor his followers as their caves weren't occupied by churches. We will only deal with the cave of Saint Paul.

The life of Saint Paul is known from the writings of saint Jerome and his work "Vita Pauli". ${ }^{26}$ Saint Paul was only sixteen when he fled Alexandria to escape from Emperor Decius' persecutions. Decius issued a decree ordering the people, on pain of death, to sacrifice to the ancient gods in the presence of officials to prove that they were not practicing Christians. Many preferred martyrdom rather than abjure their faith. Others chose to escape from the evils of the material world and join ascetic communities, or live a life of celibacy and poverty in extreme isolation devoting their lives to God. Saint Paul sought refuge in a cave in the eastern Desert by the red Sea, about $39 \mathrm{~km}$ southwest of the lighthouse station of $\mathrm{Za}$ 'farana, in $250 \mathrm{AD}$, where he lived there for 90 years until the age of one hundred and thirteen. The cave became a pilgrimage site. The earliest reference of this pilgrimage was that of Postumian in 401 AD. Another pilgrim from placentina (a city in Italy) visited the cave in 570 AD. ${ }^{27} \mathrm{~A}$ church was found inside this cave during the fifth century AD. This church was developed gradually to be a monastery. This monastery was abandoned and sacked by the Bedouins in the $15^{\text {th }}$ century. In the $16^{\text {th }}$ century the monastery was re-populated, but the Bedouins sacked it again. The monastery remained deserted till the $17^{\text {th }}$ century, when it was restored and re-populated. The monastery consists of four churches. We will focus here on the ancient cave-church of Saint Paul. ${ }^{28}$

This cave church is unique in its architecture and decoration (Pl. $7 \& 8$ ). The church consists of two parts: an interior part and an exterior one. The interior part was cut out 
of the rock and consists of a group of natural caves. The oldest part consists of the cave of Saint Paul and his cenotaph. None of them contains now paintings. Later, this old part was enlarged and a nave and a corridor with a staircase were dug out. In the $18^{\text {th }}$ century, this cave-church was restored and extended with the exterior part that consists of three domed-rooms constructed on its northern side. These sanctuaries were dedicated to the twenty four elders of Revelation, Saint Paul, and Saint Anthony. A new staircase was created in the west-room (Dome of the Martyre). The church is now accessible via this staircase. ${ }^{29}$

The church was restored in 1713. The paintings on the walls of the cave date to the same restoration work, portraying biblical subjects such as the archangels Michael, Gabriel, and Raphael, as well as the angel and Aniel's three companions, Hananiah, Mishael and Azariah, respectively called Shadrach, Meshach and Abednego by the officer of King Nebuchadnezzar. However the sanctuary of St. Anthony preserved wall paintings that date to the first half of the fourteenth century. Here, we can just make out depictions of Christ enthroned, the annunciation, St. John the Baptist, angels and archangels. ${ }^{30}$

At Asyut also there is another cave-church at El-Maabda village known as the Monastery of Saint Mena the Miraculous or the hanging Monastery (Pl. 9). It seems that Saint Mena stayed in this cave during his escape from the persecution of Emperor Diocletian. This Monastery was established at the end of the $4^{\text {th }}$ century AD. It consists of a cave with a rock-cut altar. Beside this cave there is another church known as the church of Virgin Mary and the archangel Michael. The chapel of this church was cut in the rock. This cave-church was probably the one mentioned by El-Maqrisi in his book:

"is a small monastery, hanging onthe mountain and hewn of stone, on a rock below which there is a steep precipiceso that it can neither be reached from above nor below. There are no steps,but there are incisions cut in the mountainside; and if any one wishes to ascenda long pole is let down to him, which he grasps with both hands, and by placinghis feet in the incisions so ascends. The monastery contains a mill driven byan ass. The monastery, which rises above the Nile in view of Manfalut andUmm alKusur, stands opposite to an island surrounded by water called Shakalkil,on which are two villages, one called Shakalkil, the other BaniShakir. Themonastery keeps a festival, at which Christians assemble, and bears the nameof Saint Mennas, one of the soldiers persecuted by Diocletian, in order that hemight abjure Christianity and worship idols; but as he remained constant in hisfaith, Diocletian caused him to be put to death on the 10th of Haziran or1 6th of Babah". ${ }^{31}$

\section{Hermits Caves}

Caves were places that were easily enhanced for monastic use naturally occurring srevices presented existing walls that could be refined with plaster and then extended with a courtyard in front of cave. In sites atGebelan-Naqlun in the Fayyum, the cliffs by the Red Sea, and settlements at Deirel-Dik, DeirSanbat, and Deiren-Nasara,we find 
evidence of monastic dwellings carved out of the natural caves and cliffs of the hillsides.

Inside the monastery of Al-Kusair(now it is vanished) there was the cave-church of Saint John the Baptist and forerunner. The early travellers described it. It had a stone roof supported on a pillar. In the midst of it, and on the roof, were ecclesiastical paintings. On the mountain there are many caves (Pl. 10), one of them is the cave of Saint Arsenius (to whom the monastery was dedicated), and it contains the stone which he used as a pillow. ${ }^{32}$ Emperor Theodosius summoned Arsenius to teach his son; but Arsenius thought that the emperor wished to kill him, and therefore, fled to Egypt wandered over the country as far as the Muqattam hills, east of Tura. He stayed in this cave for about 10 years from 434 till 444 AD. Then he went to Alexandria and returned to the cave at Mouqattem in $447 \mathrm{AD}$ stayed there for two years till he died in 449 AD. Arcadius sent and caused a church to be built over his tomb and this is what is known now as the monastery of al-Kusair. The relics of the saint were transferred to Constantinople to be buried inside a new church built for him. ${ }^{33}$ This deir was destroyed at the end of the $14^{\text {th }}$ century $\mathrm{AD}$, and became deserted. Excavations occurred in this place in the 1940s. Nowadays, the entrance of the cave of Saint Arsenius is closed by quantities of marble and blocks from the workshops placed in the mountain.

Behind the village of Dair Abu Hinnis at El-Minya, and in the mountain there is the cave-church of Saint John the Short (Pl. 11). He was born in 339 AD, around the Theban region. His desire for monastic life led him since his early years to remote places where he trained himself for this austere lifestyle.He lived in Wadi Al-Natrun, and fled to this area in $407 \mathrm{AD}$ after the Wadi Al-Natroun had been attacked by raiders. The cave-church is part of 37 caves extending over two kilometers. This church was built into two or three ancient caves. The narthex is unusually large and has an entrance approached by a flight of steps. The paintings of the church date back to the sixth or the seventh century AD. ${ }^{34}$ The most important decoration are two narrative friezes with scenes from the Infancy of the Christ and Saint John the Baptist, two miracles of the Christ (the raising of Lazarus and the Wedding of Cana) and a series of Saints. On the walls of the church there are about 90 inscriptions in Coptic, Greek, Syriac and Arabic. ${ }^{35}$ In 2009 this cave-church was recorded among the Coptic monuments in Egypt, and restorations began to be done to the church started with building a staircase leading up to the cave.

There is the Monastery of al-Dik (Deir al-Dik) at El-Minya. The mountain there consists a Laura36 extends for over one and a half kilometers that dates backto the 5 th or the 6th century.37Inside one of the cave there is a church. The church itself was rectangular and had one nave with four bays and a single sanctuary. The church is noteworthy because of its numerous wall paintings of crosses. 38 In addition, there is a two story cave monastery hewn from the rock dates back to the 10th century. The entire complex appears to have been surrounded by a high enclosure wall. The settlement itself was founded by Abba Apollo. Probably the monastery had already 
been destroyed or abandoned before the thirteenth century with the decline of Antinopolis, that's why it was not mentioned by El-Maqrisi.

There is also the cave-church of John of Lycopolis at Asyut (Pl. 12). Saint John was born at Asyut in $T \cdot \varepsilon$ AD. He stayed in a cave near the cave that was once inhabited by the holy family during its journey to Egypt. He stayed inside this cave till his death in 394 AD. His stay in this cave wasn't an escape from a persecution but a kind of monasticism. Saint John of Lycopolis was consulted as an oracle by the Emperor Theodosius, as by many others. We knew that a eunuch was sent from Constantinople to learn from him what would be the event of the civil war. ${ }^{39}$ This cave was transformed to be a church.

It's worth mentioning here that the hermitage inside the caves was revived in the twentieth century, precisely in 1950 s, by some monks that want to emulate the fourthto - sixth-century anchoritic life. They withdrew from the monastery of the Syrians in Wadi el-Natrun to the caves of Wadi al-Rayyan. The caves were hewn out on the northern slope of the Wadi. There were two groups of caves: the eastern group consists of five caves and the western group of seven caves, including the cave-church of Saint Michael. In all caves, the stone bed was situated in the eastern part of the caves. The hermits stayed in their caves throughout the week and gathered each Sunday in the cave-church of Saint Michael. The cave-church of Saint Michael is divided into three parts: an apse, a nave, and a narthex. The nave can be reached by descending four steps. On the northern side of the nave, there is a stone bench with a small library at its eastern side. By 1970s the monks left this Wadi and moved to the monastery of Saint Macarius in Wadi el-Natrun. ${ }^{40}$

\section{The holy Family caves}

There are also the cave-churches that were once inhabited by the Holy Family during its journey in Egypt (Pl. 13). The churches in these cases were built by these caves or upon them. Examples can be seen in the churches that commemorate the journey of the holy family, whether in Lower or Upper Egypt. Here, the researcher will only deal with the churches that exist inside the cave or that which used the cave to be a main part in the church. This type of cave-churches is few.

At Samalut - El-Minya, there is a cave-church known as the church of the Holy Virgin at Gebel el-Tayr(Pl. 14). This cave was once inhabited by the holy family during her journey to the Egypt. This place was the last place where the holy family stayed in, and from which the return journey began. This church was established by Queen Helena in the fourth century AD, as mentioned on the entrance of the church (Pl. 15). We can read:

"This church was established by the queen Saint Helena, mother of Emperor Constantine the Great, in the name of the virgin Mary at the mountain of the bird in 328 AD”.

The church has a basilica plan. It consists of a nave supported by 12 columns and surrounded by three wings. ${ }^{41}$ The church attracts annually tens of thousands of 
pilgrims who came to celebrate the feast of the assumption of the Holy Virgin in August 22.

There is the cave-church in the monastery of the Virgin Mary at El-Ganadla, Asyut (Pl. 16). The monastery is located in Pharaonic quarries to the west of the village of alGanadla on the left bank of the Nile, and is about twenty-five kilometers south of Asyut. The mountain here possessed many caves that were inhabited by the hermits. We will concern only with one cave, in which the Virgin Mary hid in during her journey in Egypt. The cave was transformed later to be a church by Saint Macrobius. The iconostasis in this church consist of stone re-assembled in the first century AD, depicted with the shapes of the hieroglyphic Ankh sign, and offerings. Some crosses, olive branches, and a fish were carved on it. The church has two altars: the main one bears the name of the Virgin and surmounted with a dome, the other one bears the name of the archangel Michael and surmounted also with a dome. At the western end of the cave are numerous wall paintings. All the architectural elements of the niches, walls and ceilings in the church were painted, probably in the sixth century. These early murals were plastered over in the eleventh or twelfth century and repainted with a series of saints, angels, and, on the north wall, Communion of the Apostles.

There is the cave-church of the holy Virgin Mary at Deir Durunka (Pl. 17). The village of DeirDurunka is situated ten kilometers south of Asyut. The holy family stayed in one of the caves of the village's mountain during their escape. The caves of this mountain were inhabited by hermits and by Christians escaping persecution. The ruins of this ancient cave-church are still visible. An annual festival used to be held on August 7-22 to commemorate the visit of the holy family. Thousands of pilgrims attend the festival and inhabit the caves. ${ }^{42}$

\section{Cave-churches in Christian community}

There are also the cave-churches that were established in a Christian community who inhabited an area full of Mountains. We have few examples of this type:

There is the cave-church of WadiSarga at Asyut. The church is called "the church of Saint Thomas" (Pl. 18). This site was a quarry site starting from the Pharaonic to the Roman era. By the $7^{\text {th }}$ century AD, a Christian settlement had been established at this site. It seems that the Christian settlers re-used a former gallery quarry and transformed it into a church. The church consists a nave with an apse in the east wall preceded by an antechamber. The area surrounding the church revealed the existence of houses and cemeteries. ${ }^{43}$

It's worth mentioning also that the modern history of Egypt provided us with more seven cave-churches in El-Moqattam mountain in south-eastern Cairo, in an area is known as "Garbage City". The Zabbaleen are descendants of farmers who started migrating from Upper Egypt to Cairo in the 1940s. At the end of 1969, the governor of Cairo issued a decree to settle a large group of Zabaleen under the cliffs of the Moqattam inside tin huts. They founded their churches into the caves found in the Mokattam, of which the church of St. Simon the Tanner is the largest that was built in 1976 (Pl. 19). ${ }^{44}$ 


\section{Conclusion}

- The ancient Egyptians enhanced the natural caves to be used as a worship center.

- The god in the ordinary city-temples represents the emergence of the god from the waters of chaos on the primeval mound. However, the cave resembles the womb from which the god will be born.

- The earliest example of these cave-shrines was found at Elephantine and dedicated to goddess Satet.

- It seems that the idea of the cave-shrine was Nubian and then spread inland during the Middle Kingdom.

- The cave-shrines that were carved in the Middle Kingdom related to the mining expeditions that were sent to Sinai and the Red Sea.

- The real spread of the cave-shrine dates back to the New Kingdom.Later on, kings of the New kingdom no longer used the natural caves in their worship. Instead they carved their shrines inside the rock, an art that is known as the rock-cut art.

- A new innovation appeared in the New Kingdom, which is the rock-cut temple.

- It is notable also that the divinity to whom most of the cave shrine was dedicated was either Amun or Hathor.

- The Graeco-Roman period, provided us with only one example of the cave-shrine, which is the one found at Tehne. On the contrary, this era provided us with numerous examples of rock-cut shrines.

- The cave-shrines reappeared in the Byzantine period in what is called the cavechurches.

- The cave-churches in Egypt can be classified into four categories.

- The refuge caves: they were once inhabited by the saints who escaped from the persecution and sought refuge in these caves. Two examples can be found: the cavechurch of Saint Paul by the red sea, and the Monastery of Saint Mena the Miraculous at Asyut.

- The Hermit Caves: they were once inhabited by the hermits and then transformed to be a church. Four examples can be traced: the cave-church of Saint John the Baptist at Moqattam, the cave-church of Saint John the Short at El-Minya, the Monastery of alDik at el-Minya, and the cave-church of John of Lycopolis at Asyut.

- The Holy Family caves: they were once inhabited by the Holy Family during its journey in Egypt. We will only concern here with the churches that were founded inside the cave. Four examples can be traced: the church of the Holy Virgin at Gebel el-Tayr (El-Minya),Al-Adra church inside Deir al Muharraq (Asyut), the monastery of the Virgin Mary at El-Ganadla (Asyut), and the church of the holy Virgin Mary at DeirDurunka(Asyut).

- The cave-churches in the Christian community: it appeared in the Christian community that inhabited the mountains. the church of Saint Thomas at Asyut, and the recent Church of St. Simon at El-Moqattam. 


\section{Plates}

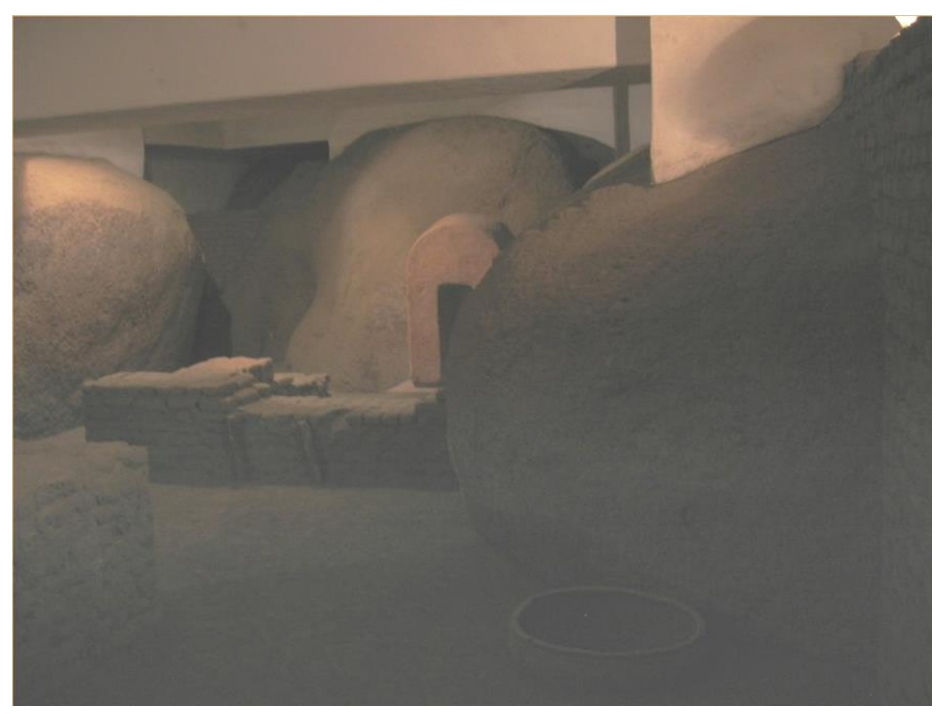

PI. 1

Cave-shrine of Satet, Elephantine, $1^{\text {st }}-2^{\text {nd }}$ Dynasty

After: Verner M., "Temple of the world: Sanctuaries, cults and Mysteries of Ancient Egypt, Egypt, 2012, 514.

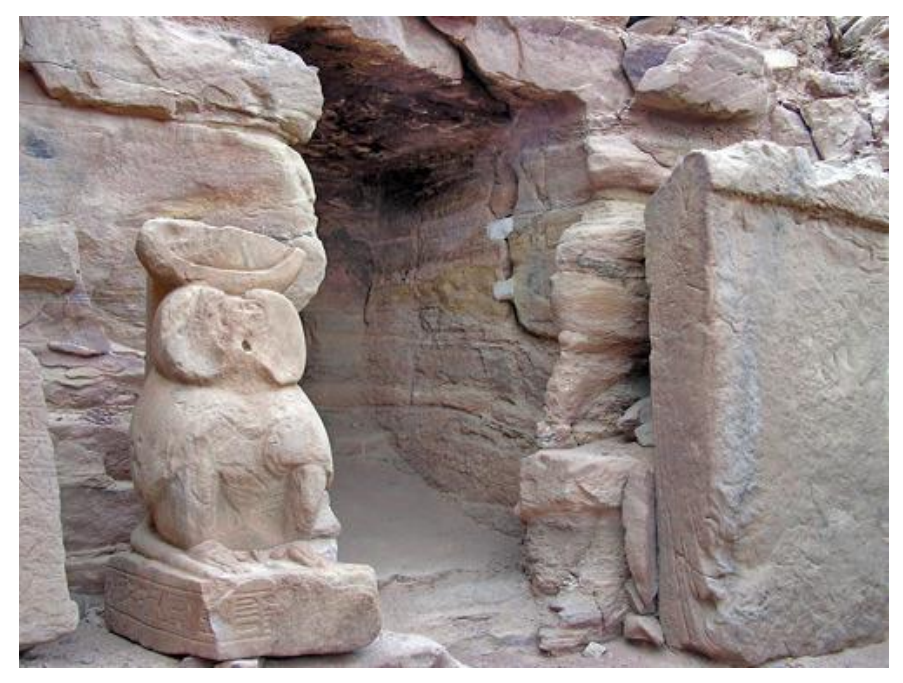

PI. 2

Cave-shrine of Hathor, Serabit El-Khadem, Sinai, $12^{\text {th }}$ Dynasty

After: Lesko S., “The Great Goddesses of Egypt”, U.S.A, 1999, 98. 


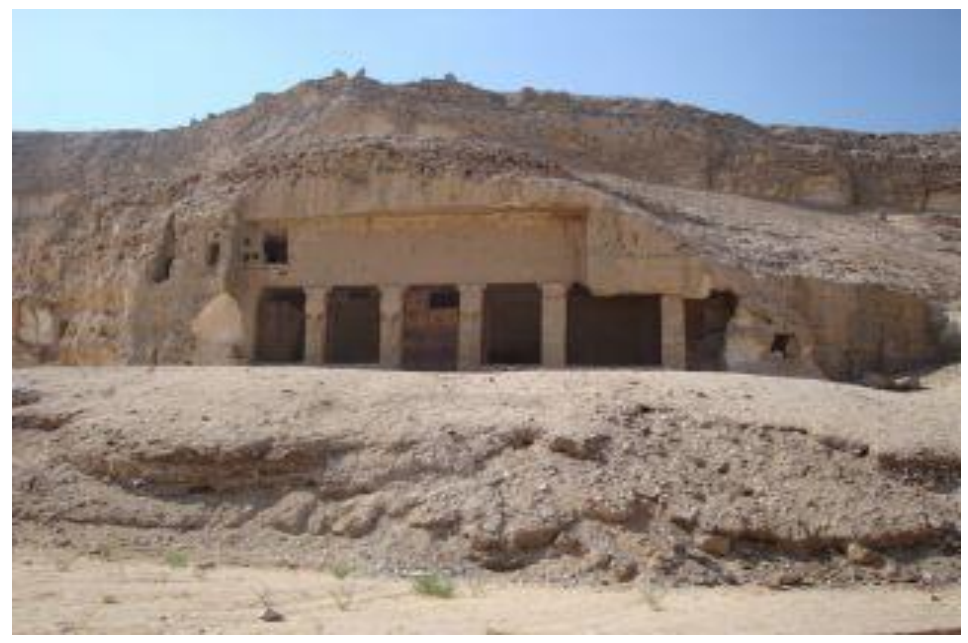

PI. 3

Temple of SeposArtimedos, Beni-Hassan, $18^{\text {th }}$ Dynasty

After: MurrayM., “Egyptian temple”,Britain, 2004, Pl. VIII.
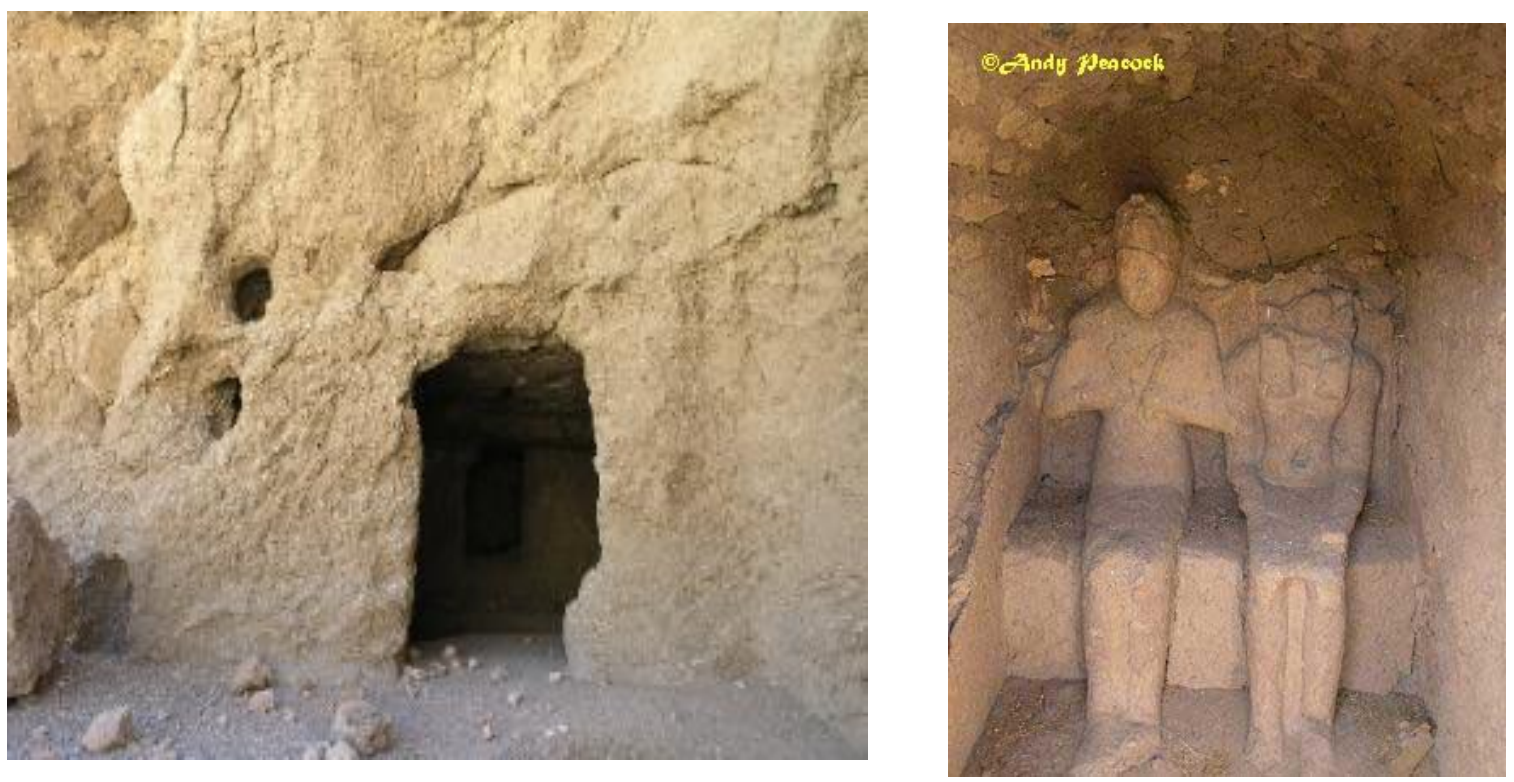

Pl. 4

The cave-shrines at Deir El-Medineh, $18^{\text {th }}$ Dyn. 


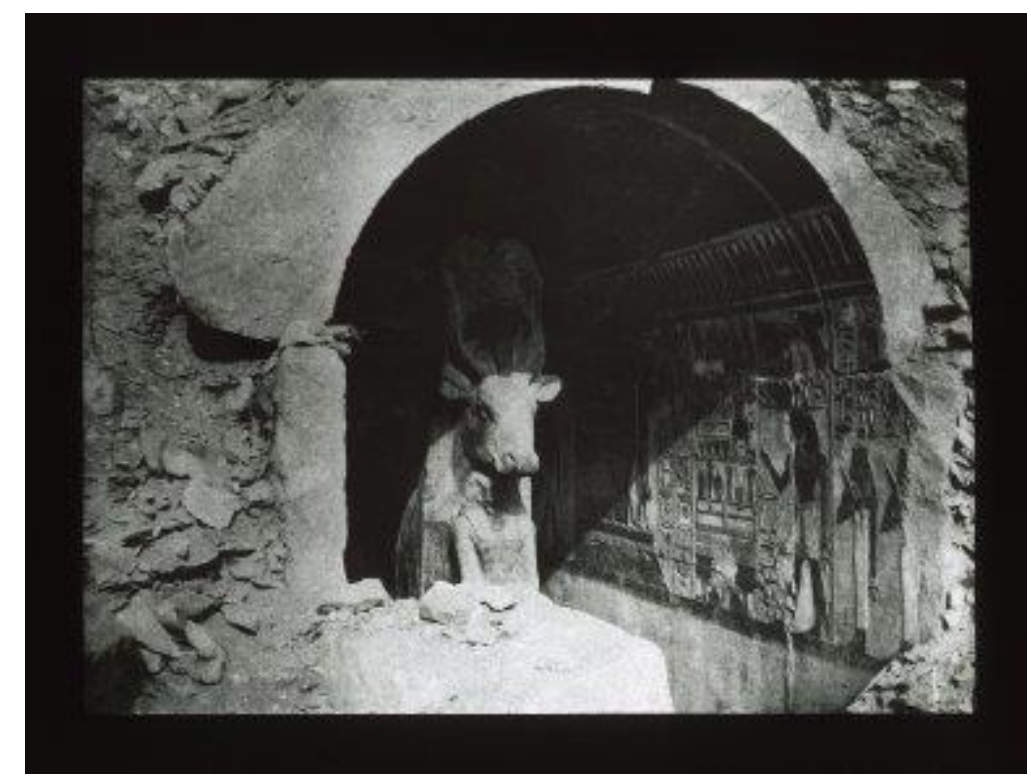

Pl. 5

The cave-shrine of Hathor at Deir El-Bahari, $18^{\text {th }}$ dyn.

After: Naville E., “the VIth Dynasty temple at Deir el-Bahari I', London 1907, Pls. 27 - 31.

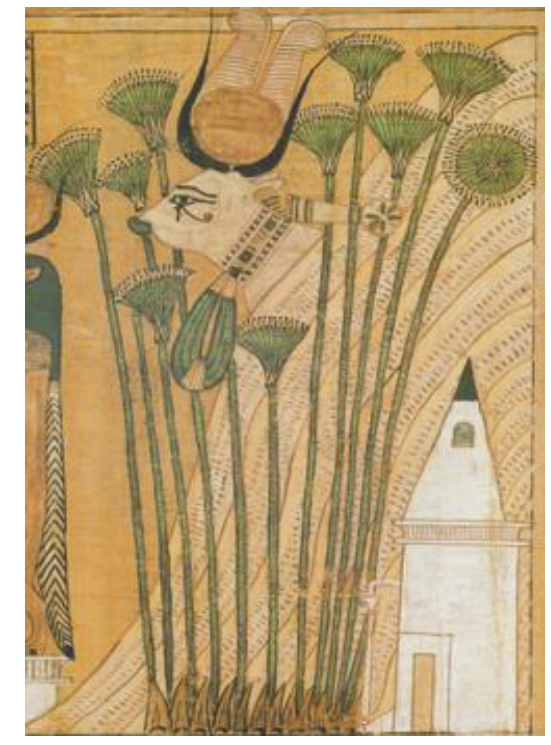

Pl. 6

Hathor emerges from the Theban Mountain

Book of the dead, New Kingdom

After: Faulkner R., “The Egyptian Book of the Dead”, 2008, Pl. 37. 


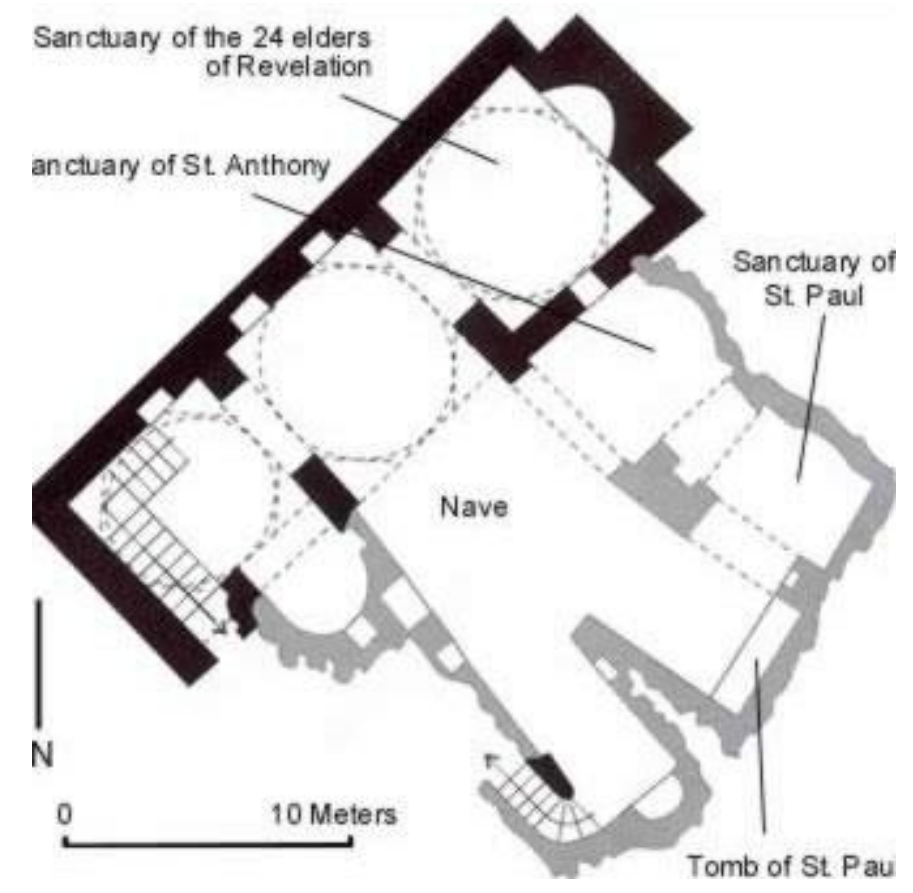

The grey lines referred to the rock-cut part of the church

PI. 7

Plan of the Cave-church of St. Paul, Red Sea

After:Gabra G., Coptic monasteries, 87-90.

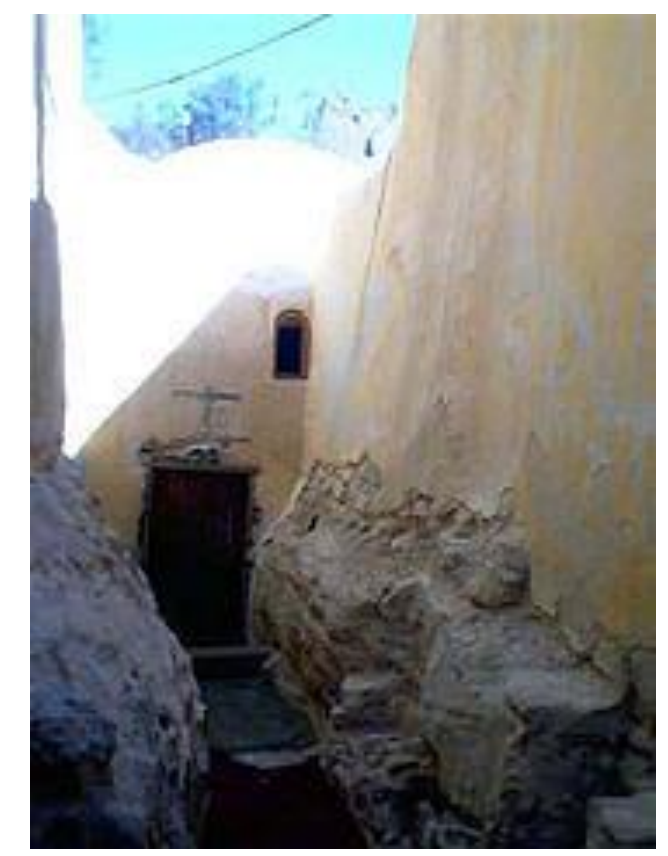

PI. 8

The entrance to the Cave-church of St. Paul, Red Sea

After: Gabra G., Coptic monasteries, 87-90. 


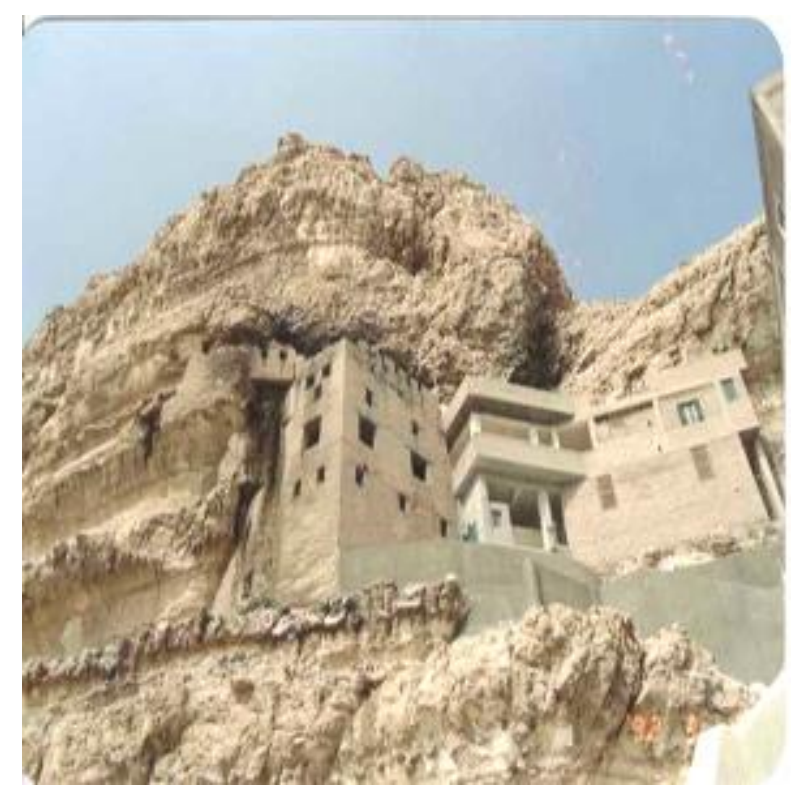

PI. 9

The Hanging Monastery, Asyut.

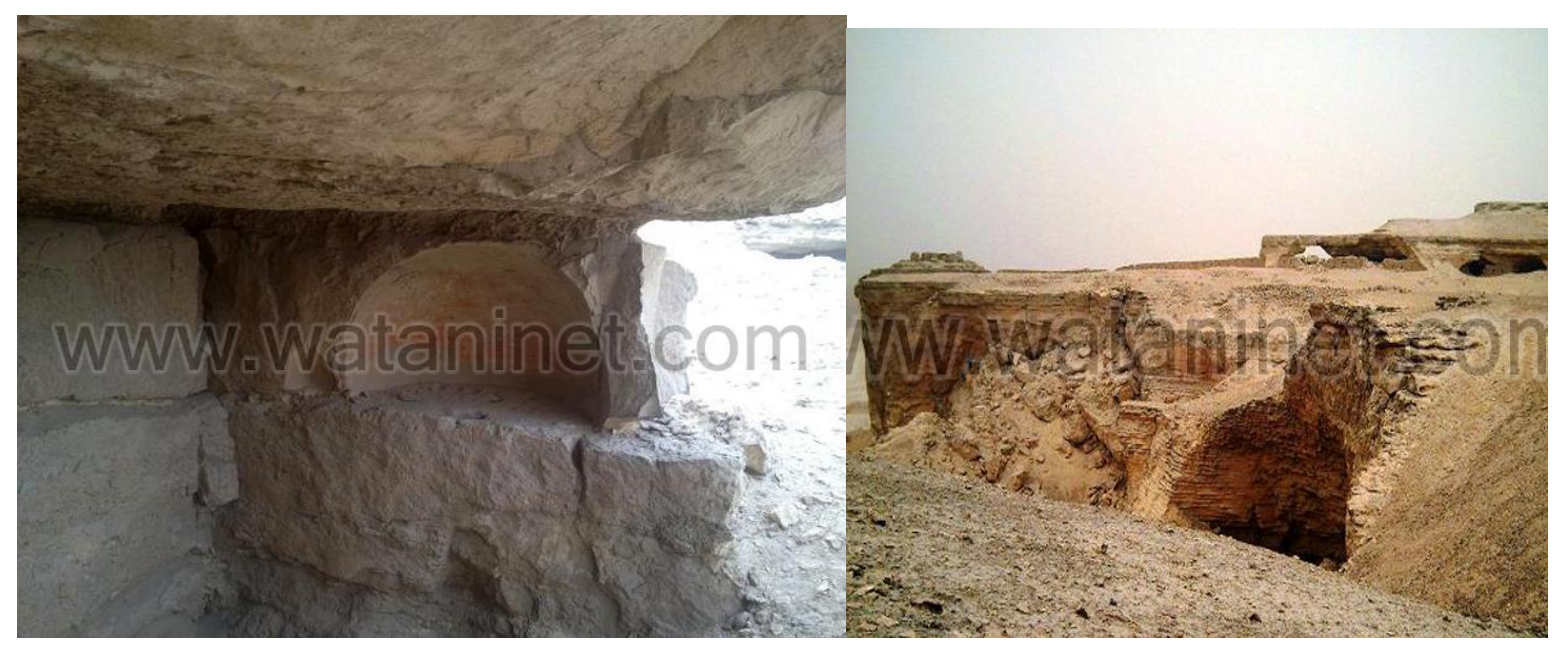

Pl. 10

The hermit caves in El-Mokattam Mountain, Cairo 


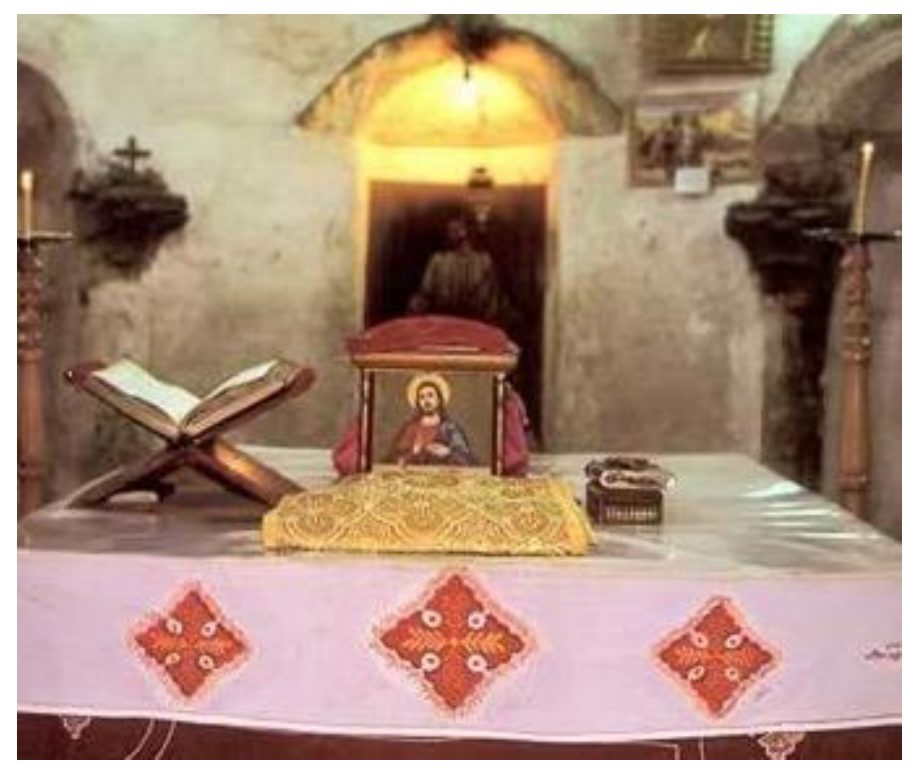

PI. 11

The cave-church of Saint John the Short, El-Minya

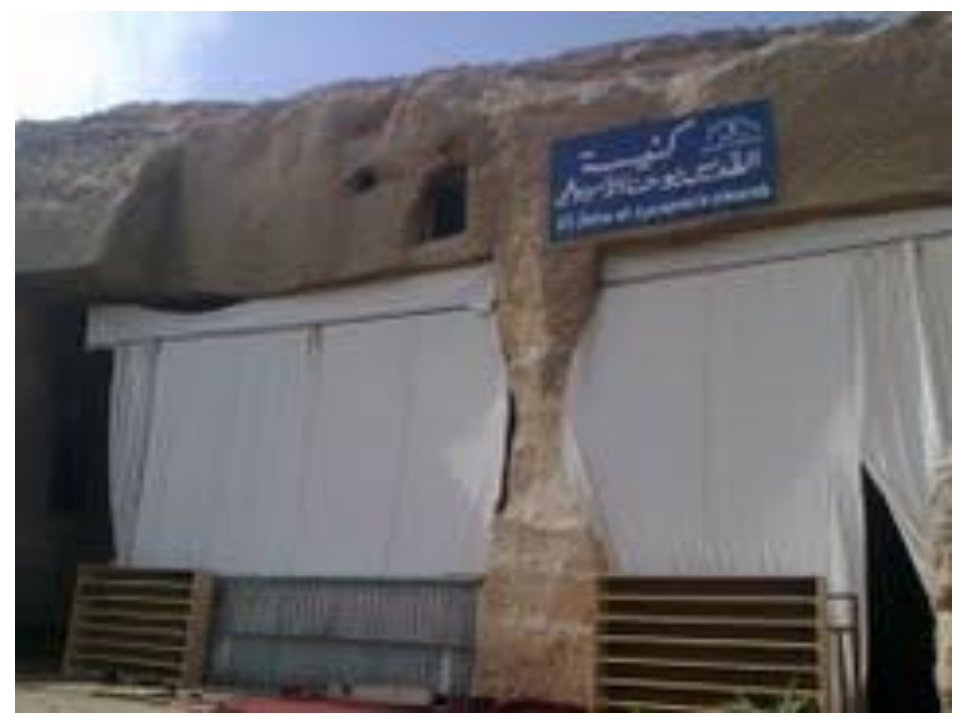

Pl. 12

The cave-church of John of Lycopolis, Asyut 


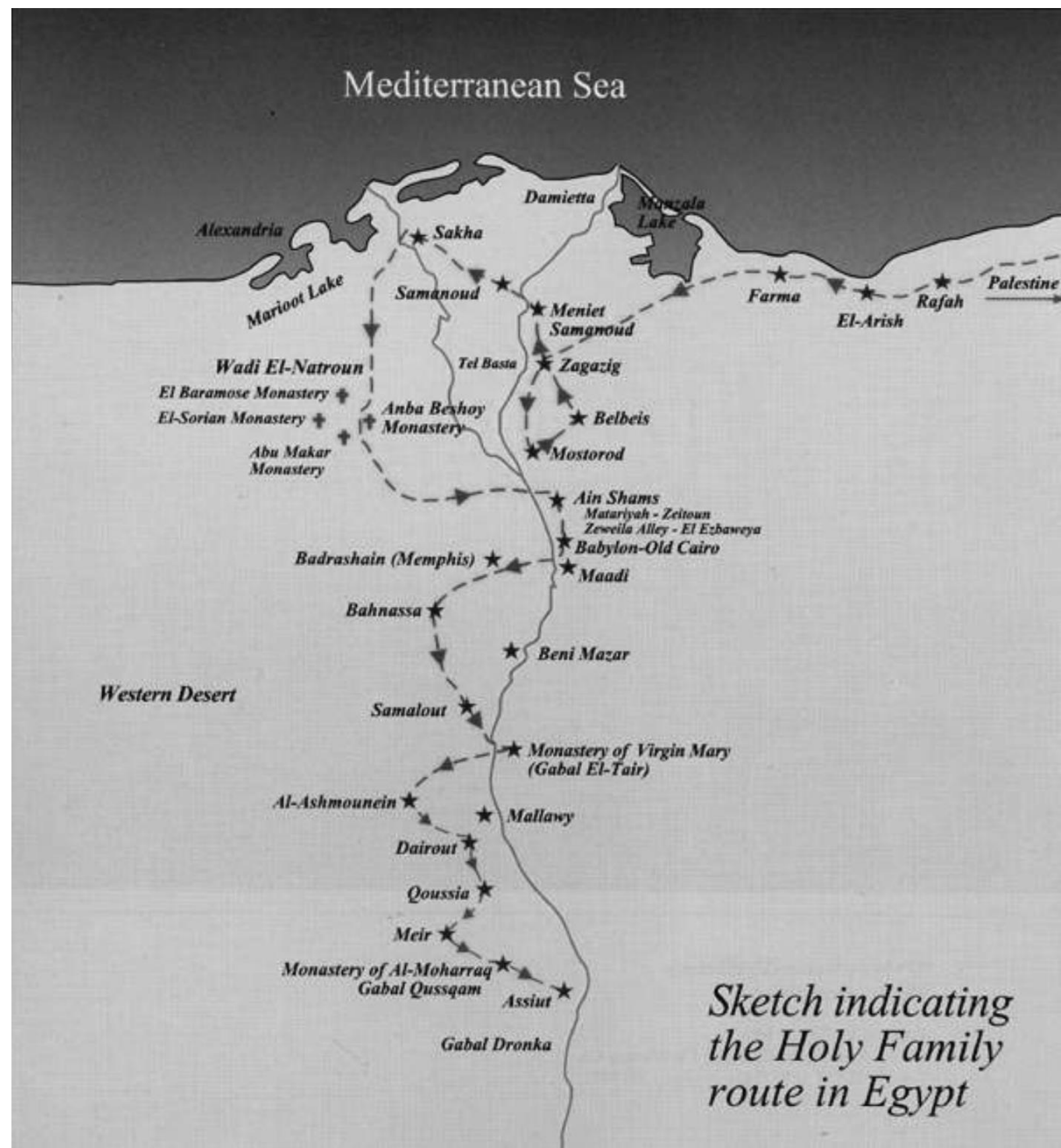

Pl. 13

The Journey of the Holy Family in Egypt 

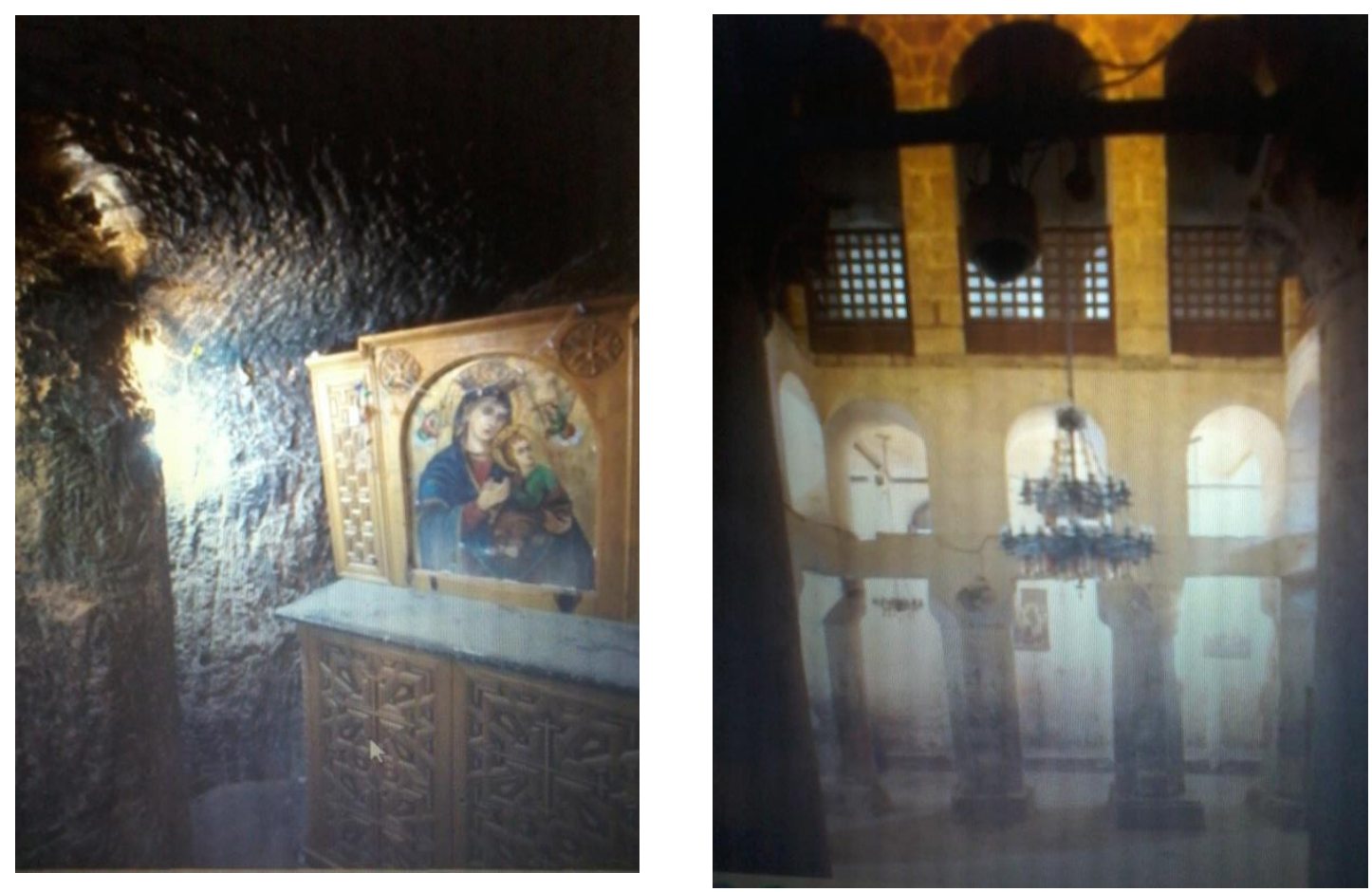

Pl. 14

The Cave-church of the Holy Virgin, Gebel el-Tayr, Minya

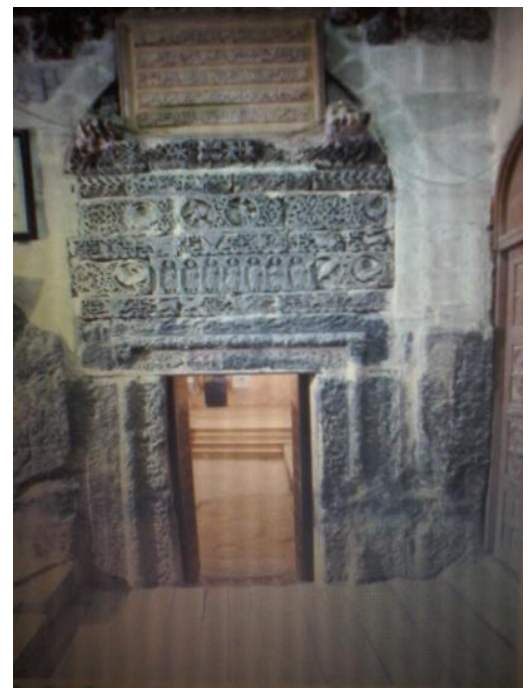

Pl. 15

The entrance to the cave-church of the Virgin, Gebel el-Tayr 

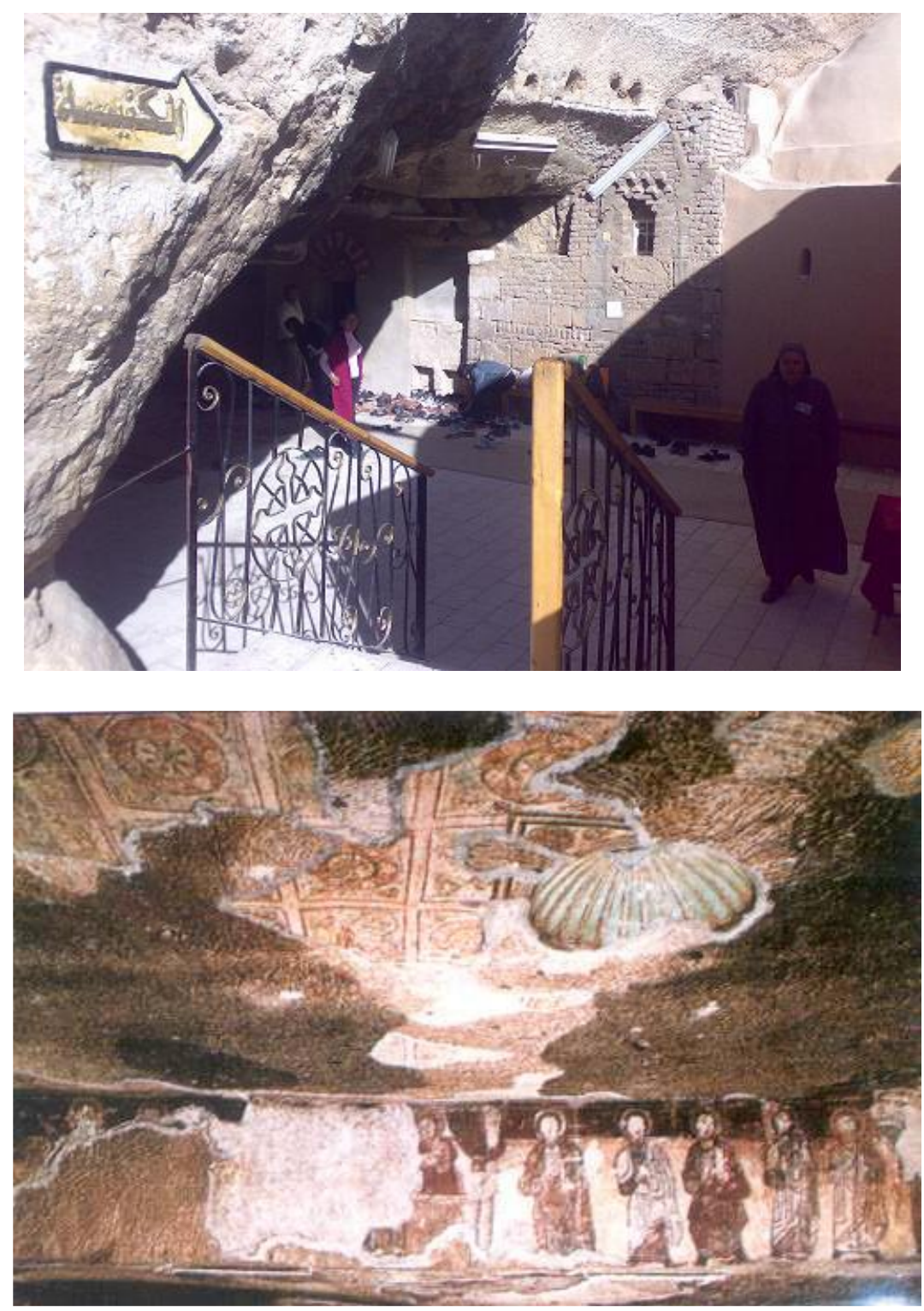

Pl. 16

The cave-church in the monastery of the Virgin Mary, El-Ganadla, Asyut 

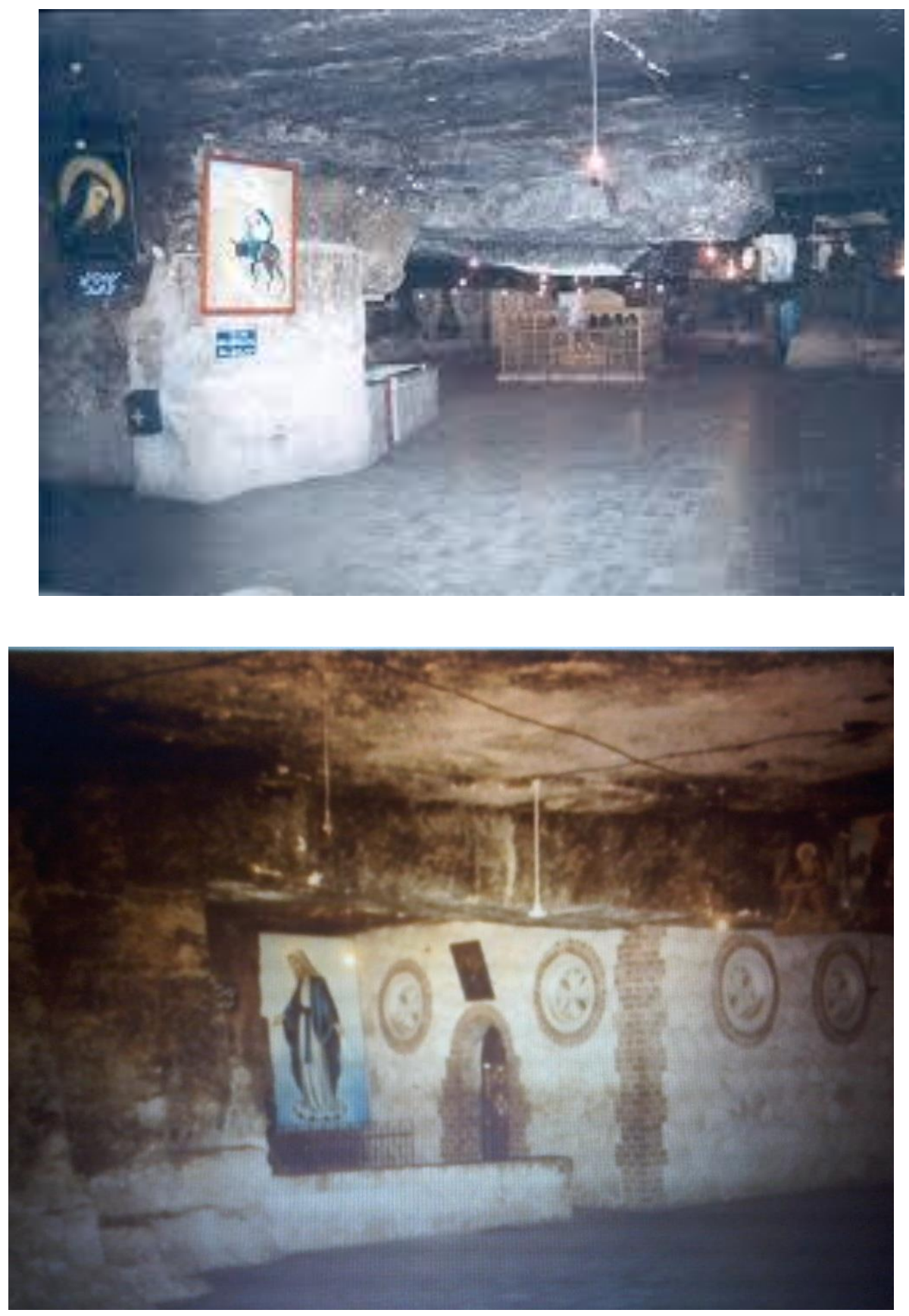

Pl. 17

Cave-church of the holy Virgin Mary, DeirDurunka, Asyut 

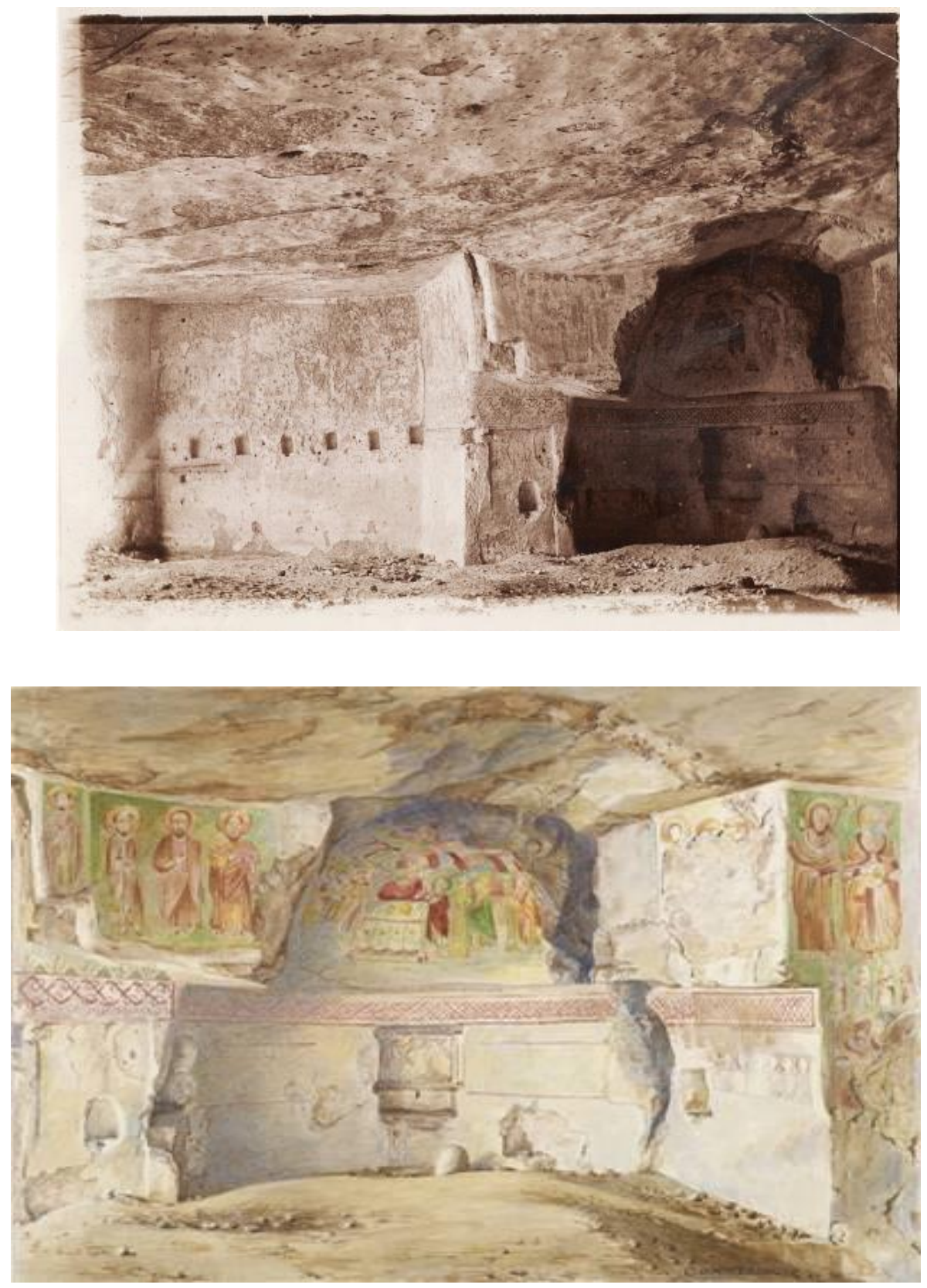

Pl. 18

Cave-church of Saint Thomas, WadiSerga, Asyut

After: O’Connell E., excavation at WadiSarga, Fig. 40. 

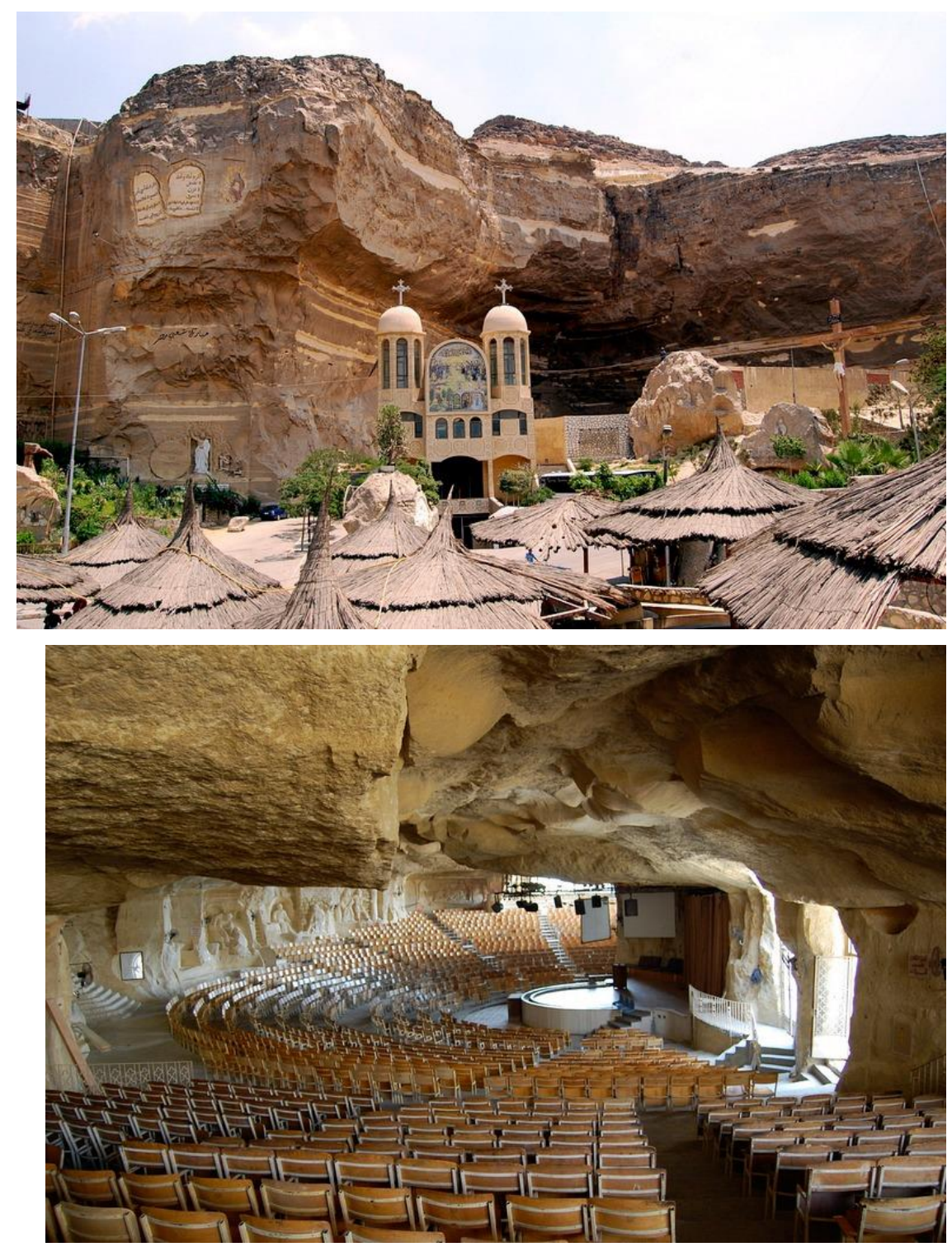

Pl. 19

Cave-church of St. Simon the Tunner, El-Mokattam 


\section{References}

${ }^{1}$ L.Torok, "Between Two Worlds: the frontier region between ancient Nubia and Egypt 3700 BC - 500 AD”, Leiden ,2009, 129.

${ }^{2}$ B. Williams, "The Cave shrine and the Gebel",in: CzernyE, eds. Studies in honour of Manfred Bietak, Vol. III, 2006.

${ }^{3}$ R. Giveon, "Le temple d'Hathor a Serabit el-Khadem”, Archeologia44(1972), 64 - 69.

${ }^{4}$ S. Lesko, "The Great Goddesses of Egypt", U.S.A, 1999, 98.

${ }^{5} \mathrm{~K}$. Bard, "Spatial use of the twelfth Dynasty Harbor at Mersa/WadiSawasis for the Seafaring expeditions to punt",Journal of ancient Egyptian Interconnections, Vol. 2:3 (2010), 1-13.

${ }^{6} \mathrm{~K}$. Bard , "An introduction to the archaeology of ancient Egypt”, 2007, 172 - 173.

${ }^{7}$ B. Newberry, “Beni Hassan”, London, 1893.

${ }^{8}$ J. Černý, “A community of workmen at Thebes in the Ramesside period”, Cairo, InstitutFrancaisd'archeologie Orientale du Caire, 1973.

${ }^{9} \mathrm{E}$. Naville, "The temple of Deir El-Bahari, Band IV: the shrine of Hathor and the southern hall of offerings", London, 1901, 6.

${ }^{10}$ J. Lipinska, “The temple of Tuthmosis III, Deir el-Bahari II”, Warsaw, 1977, 38 - 45.

${ }^{11}$ A. Kucharek, "Gebel el-Silsila”,UCLA Encyclopaedia of Egyptology, 2012, 6 - 9 ;R. Caminos, "Gebel es-Silsilah I: the shrines", Archaeological survey of Egypt 31, London, 1963.

${ }^{12}$ C. Booth, "Horemheb: The forgotten Pharaoh", Britain, 2010, XCIV - XCVII

${ }^{13}$ J. Larson, "Lost Nubia”, The oriental institute of Chicago, 2006, 16 - 19 ; M. Sidro, “Der Felstempel von Abu Oda. EinrarchitektonischeUntersuchung”, Hamburg ,2006.

${ }^{14} \mathrm{R}$. Klemm, "Gold and Gold mining in ancient Egypt and Nubia: Geoarchaeology of the ancient gold Mining sites in the Egyptian and Sudanese eastern Deserts”, Heildelberg, 2013, 193.

${ }^{15}$ P. Shinnie, "Ancient Nubia", 2009, 93.

${ }^{16}$ A. Sayce, "CaireneFolkolore”, Folk-Lore, Vol. 11, (1900), 392

${ }^{17}$ H. RICKE, “Ausgrabungen von Khor-Dehmitbis Bet el Wali”, TheUniversity ofChicago Oriental

In st it u te Nubi a Expedition, vol. II. Chicago, 1967, 25-30, Pls. $12-15$.

${ }^{18}$ S. West, "The Greek version of the legend of Tefnut”,JEA 55,(1969), 161-183 ;B. Richter, “On the Heels of the Wandering Goddess”,In: Dolinska M. And Beinlich H., eds., AchteAegyptologischeTempeltagung, Germany, 2010, $162-167$.

${ }^{19}$ R. El Farag, "Recent archaeological explorations at Athribis",MDAIK 41(1985), 1-8. ; www.unituebingen.de/aegyptologie

${ }^{20}$ R. Giveon, “Tehne”, L̈̈ VI, Col. 304-305 ; K. Shobo, “Akoris, report of the excavation at Akoris in Middle Egypt 1981 - 1992”, Kyoto 1995, 17-26.

${ }^{21}$ G. Wagner, "Nouvelle inscriptions d'Akoris”, In: Hommages a Serge Sauneron II, IFAO, 1979, 51-55. ; P.

Romeo, "Documenti relative au culticastrensi in Egitto (I-III Sec. D.C),Annalidell'AssociazioneNomentana 6,(2003), 63.

${ }^{22}$ E. Von Dassow, “The Egyptian Book of the Dead: The book of going forth by day”, 1998, 170, Pl. 37.

${ }^{23}$ P. Grossmann , "Architectural Elements of Churches, Crypt”, In: The Coptic Encyclopedia, Vol. 1, 1991, $194-226$.

${ }^{24}$ It is an early form of the monastic life, in which the person searches for a spiritual advice and counsel. The

Christian hermits have often lived in isolated cells or hermitages, whether a natural cave or a constructed dwelling situated in the desert.

${ }^{25}$ O. Meinadure, Two Thousand years of Coptic Christianity”, The American University Press, Cairo, $2000,259$.

${ }^{26}$ F. Bacchus, "St.Paul the Hermit", In: The Catholic Encyclopedia, Vol. 11, New York, 1911.

${ }^{27}$ G. Gabra, "Coptic monasteries”, Cairo, 2002, 87-90.

${ }^{28}$ G. Gabra, "Coptic monasteries, 87-90

${ }^{29}$ G. Gabra, "Coptic monasteries, 87-90.

${ }^{30} \mathrm{P}$. Moorsel, "le monastere de Saint-Paul pres de la mer Rouge”, IFAO, 2002.

${ }^{31}$ A. Salih, "the churches and Monasteries of Egypt and some Neighbouring countries”, original print 1895, reprinted London, 2013, 309.

${ }^{32}$ A. Salih, 2013, 151.

${ }^{33} \mathrm{~A}$. Buttler, "The lives of the primitive fathers, martyrs and other principle saints", Vol. VII, Edinburgh, 1799, 272282.

${ }^{34}$ O. Meinadure,Two Thousand years of Coptic Christianity”, 219.

${ }^{35}$ H. Williams, "Report of the 2004-2005 Campaigns of the Belgian Mission to Deir al-Barsha",MDAIK 65, (2009), 430 .

${ }^{36}$ A Laura is a form of monasticism consists of isolated cells.

${ }^{37}$ M. Martin, “La Laure de Der al Dik à Antinoé”, Bibliothèque des étudescoptes 8, Cairo, 1971. 
${ }^{38}$ S. Donadoni, "Epigrafiaminore di Antinoë.", In Studi in onore di Calderini e Paribeni, Vol. 2, Milan, 1959, $479-87$.

${ }^{39}$ H. Martineau ,“Eastern life: present and past”, Vol. 1, Philadelphia, 1848, 44-45.

${ }^{40}$ O. Meinadure, Two Thousand years of Coptic Christianity", 253 - 255.

${ }^{41}$ O. Meinadure O., Two Thousand years of Coptic Christianity, 213 ;

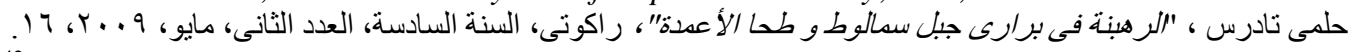

${ }^{42}$ O. Meinardus, Two Thousand years of Coptic Christianity”, 226.

${ }^{43}$ E. O'Connell, "R. Campbell Thompson's 1913/14excavation at WadiSarga and other sites", British Museum Studies in ancient Egypt and Sudan 21, 2014, PP. 92-121.

${ }^{44}$ www.samaanchurch.com ; L. Iskandar, "Mokattam Garbage village”, Cairo, 1994, 114 ff. 